\title{
CRYPTOGRAPHY OF JAVA LANGUAGE USING BASA WALIKAN METHODS IN YOGYAKARTA
}

\author{
Hero Wintolo ${ }^{1)}$, Asih Pujiastuti ${ }^{2)}$, Ellyana Mega Dewantri Astuti ${ }^{3)}$ \\ ${ }^{1,2,3}$ Departemen Informatika \\ Sekolah Tinggi Teknologi Adisutjipto Yogyakarta \\ Jl. Janti, Blok-R, Lanud Adisucipto Yogyakarta \\ Email : ${ }^{1}$ herowintolo@stta.ac.id
}

\begin{abstract}
Basa Walikan can be used as one of the methods in cryptography because the Basa Walikan character exchange process is not easily understood by all people who can speak Javanese. Basa Walikan used in this research is Basa-Walikan in Yogyakarta, which is sourced from Javanese script characters written in a two-line countdown rule. In Roman characters it becomes ha, na, ca, ra, ka, da, ta, sa, wa, la, pa, dha, ja, yes, nya, ma, ga, ba, tha, nga. The characters in Javanese script are written in 4 (four) lines. The process of character reversal in Basa Walikan uses the mechanism of the first line exchanged with the third line and the second line is swapped to the fourth line as well as the opposite. In this research software for message safety with Basa Walikan was made. From the White Box and Black Box test results it can be concluded that the encryption process and the description process are in accordance with the design of the application being made. If the word being tested is two consonants $m$ and $p$ that are close together, then the encryption process and the description process is done separately or by character.
\end{abstract}

Keywords: Cryptography, Basa Walikan, Web Based

\section{Pendahuluan}

Kriptografi digunakan untuk mengamankan pesan yang mana kekuatan keamanan terdapat pada kunci yang digunakan. Kunci pada kriptografi digunakan untuk menjembatani saat dilakukannya proses enkripsi-deskripsi atau deskripsi-enkripsi. Pada kunci kriptografi dibedakan menjadi dua bagian yaitu kunci simetris dan kunci asimetris. Oleh sebab itu dibuatlah sebuah aplikasi yang berfungsi untuk mengamankan pesan teks yang digunakan saat melakukan pertukaran informasi menggunakan metode Basa Walikan. Tulisan sebelumnya terkait Basa Walikan ini bersumber dari daerah Malang atau dikenal sebagai Basa Walikan Malangan[1] atau Slang Malang[2][3]. Metode Basa Walikan ini hampir mirip dengan ROT13 yang banyak digunakan dalam kriptografi tradisional di mana karakter akan diganti dengan jaraknya 13 (tigabelas) dari karakter aslinya atau dalam karakter romawi, hurufnya dibagi dua dari 26 (dua puluh enam) huruf yang ada.

Kriptografi pada teknologi informasi digunakan untuk membangun keamanan pada sebuah perangkat lunak yang dapat menggunakan Advanced Encryption Standard (AES)[4][5], Vigenere Cipher[6], Hill Cipher[7] atau Rivest Shamir Adleman (RSA)[8] sebagai metodenya. Dengan penggunaan metode yang sudah ada keamanan sebuah data dalam teknologi informasi juga belum terjamin sehingga dalam pengembangan kriptografi untuk mengamankan data ini 
kadang menggunakan cara atau metode yang dibuat sendiri, sebagai contoh algoritma lipat[9][10]. Penggunaan bahasa walikan untuk mengubah plain text menjadi chipper text hanya dapat diterapkan dalam Bahasa Jawa. Proses pengubahan karakter dalam huruf jawa ini menggeser sejauh 10 karakter sehingga chipper text yang dihasilkan dapat dibaca tapi tidak mampu dipahami kecuali mereka yang mengenal metode Basa Walikan ini.

\section{Metode Penelitian}

Metode penelitian yang dilakukan dalam penelitian ini adalah studi pustaka untuk mempelajari konsep dan metode Basa Walikan di Yogyakarta, kemudian dilanjutkan membangun algoritma dan pemrograman aplikasi dengan bahasa pemrograman berbasis WEB. Setelah aplikasi berhasil dibuat, langkah berikutnya adalah melakukan pengujian aplikasi dengan kata atau kalimat bahasa jawa. Hasil pengujian ini dicatat dan di jadikan bahan evaluasi aplikasi yang dibuat. Aplikasi yang dibangun dinamakan Walikan.com.

\subsection{Use Case Diagram}

Use Case Diagram ini menjelaskan proses-proses hubungan antara user dengan sistem dalam menggunakan aplikasi Walikan.com. Use Case Diagram menjelaskan aktivitas yang dapat dilakukan oleh user. Jika user menjalankan aplikasi tersebut,maka user dapat melakukan beberapa aksi yaitu input kata. Kata yang sudah di inputkan dapat dienkripsi dan deskripsi. Hasil dari enkripsi dan deskripsi tampil dalam bentuk karakter dan bentuk Aksara Jawa. Selain itu user dapat melihat informasi tentang pembuat aplikasi dan panduan yang berisi Aksara Jawa yang digunakan dalam Basa Walikan beserta penjelasan. Use Case Diagram yang lebih jelas dari aplikasi Bahasa Jawa Walikan dapat dilihat pada Gambar 1.

\subsection{Class Diagram}

Class Diagram menggambarkan struktur dari aplikasi Walikan.com yang akan dibuat, dan digunakan untuk pendefinisian kelas - kelas yang akan dibuat untuk membangun sistem. Pada aplikasi Walikan.com terdapat beberapa kelas yang digunakan dan saling berelasi. Kelas yang terdapat pada aplikasi Walikan.com yaitu kelas index, kelas about, dan kelas panduan. Kelas index merupakan kelas yang digunakan untuk menampilkan halaman ketika aplikasi dijalankan. Kelas index juga digunakan untuk enkripsi dan deskripsi. Kelas about merupakan kelas yang digunakan untuk menampilkan halaman menu tentang, dan kelas panduan merupakan kelas yang digunakan untuk menampilkan halaman menu panduan yang ada pada aplikasi. Class Diagram secara keseluruhan dapat dilihat pada Gambar 2. 


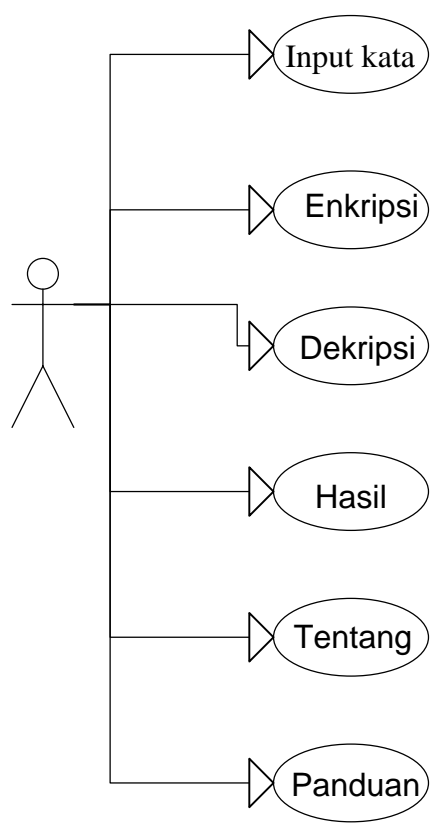

Gambar 1. Use Case Diagram Walikan.com

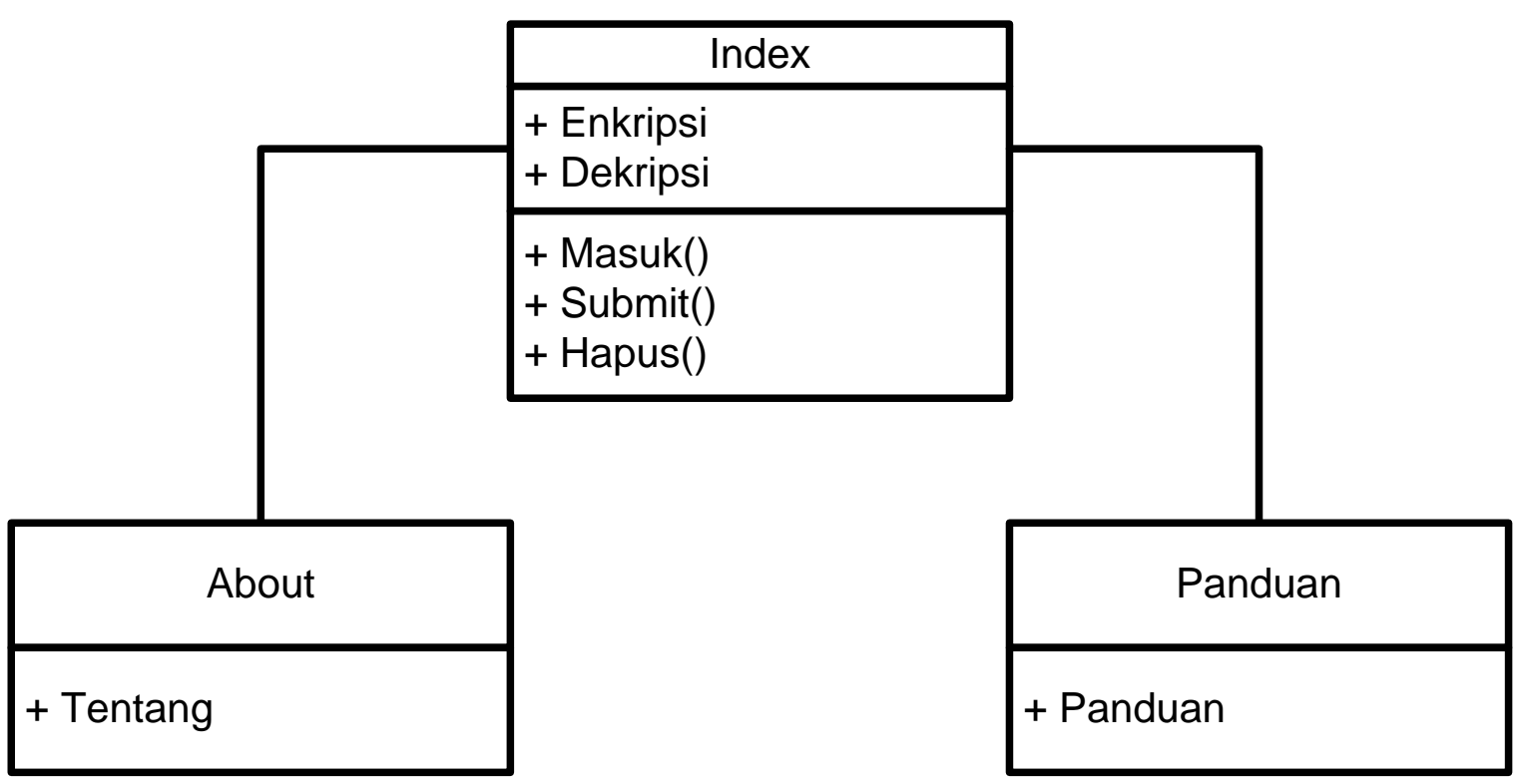

Gambar 2. Class Diagram Walikan.com

\section{Hasil dan Pembahasan}

\subsection{Halaman Menu Walikan}

Halaman aplikasi Walikan.com yang dapat dilihat pada Gambar 4 merupakan halaman awal yang akan ditampilkan saat user menjalankan dan berhasil masuk ke aplikasi. Halaman aplikasi Walikan.com merupakan halaman utama yang sekaligus menjadi halaman menu. Terdapat dua menu tambahan yaitu menu Tentang dan menu Panduan. Menu Walikan.com digunakan untuk melakukan proses enkripsi dan deskripsi dengan metode Basa Walikan. Di dalam menu Walikan.com terdapat tombol enkripsi dan tombol deskripsi yang berfungsi untuk 
melakukan proses perubahan kata yang telah dimasukkan pada kolom input bahasa Jawa atau kolom input Bahasa Jawa Walikan, dan terdapat juga tombol hapus yang berfungsi untuk menghapus input kata dan hasil dari proses yang sudah dilakukan. Pada kolom Aksara Jawa berfungsi untuk menampilkan huruf Aksara Jawa dari proses enkripsi atau proses deskripsi, jika dilakukan proses enkripsi maka Aksara Jawa yang ditampilkan dari kolom Bahasa Jawa Walikan Gambar halaman aplikasi Walikan.com dapat dilihat pada Gambar 3.

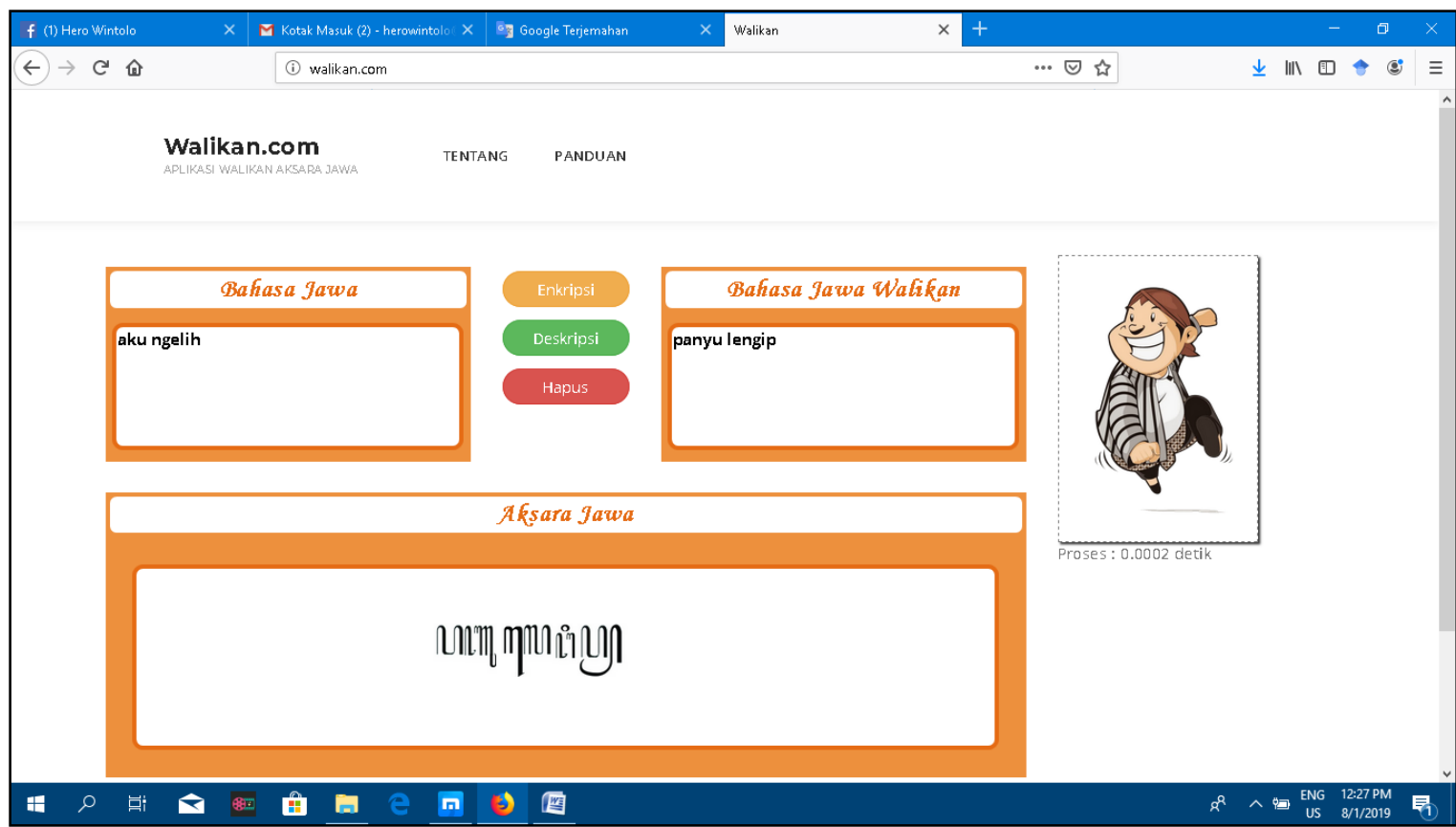

Gambar 3. Tampilan aplikasi Walikan.com yang beralamatkan di http://walikan.com/

\subsection{Uji fungsi}

Pengujian aplikasi Walikan.com dilakukan dengan memasukkan kata atau kalimat dalam Bahasa Jawa. Pengujian untuk memasukan kata dalam Bahasa Jawa yang kemudian dilakukan proses enkripsi menggunakan Bahasa Jawa Walikan terhadap kata tersebut menghasilkan sebuah kata dalam bentuk chipper text yang tidak memiliki arti ataupun makna dalam Bahasa Jawa. Kemudian kata tersebut dikenai proses enkripsi dengan hasil kembali seperti kata semula atau plain text. Ada 30 kata yang digunakan untuk ujicoba kriptografi menggunakan metode Bahasa Jawa Walikan dengan 4 diantaranya dapat pada Tabel 1.

Pengujian berikutnya dilakukan memasukan kalimat dalam Bahasa Jawa yang hasil proses pengecekan kalimat dapat dilihat pada Tabel 2. Pengujian dilakukan untuk mendapatkan data terkait dari aplikasi yang dirancang ini mampu melakukan proses enkripsi dan deskripsi pada kalimat yang dituliskan dengan menggunakan Bahasa Jawa. 
Tabel 1 Hasil Pengujian Kata

\begin{tabular}{|c|l|l|l|l|}
\hline \multirow{2}{*}{ No } & \multicolumn{4}{|c|}{ Hasil Pengujian } \\
\cline { 2 - 5 } & Plaintext & Enkripsi & Chipertext & Deskripsi \\
\hline 1 & Aku & Panyu & Panyu & Haku \\
\hline 2 & Mangan & Daladh & Daladh & Mangan \\
\hline 3 & Tumbas & Gudsab & Gudsab & Tumbas \\
\hline 4 & Ora & Poya & Poya & Ora \\
\hline 5 & Numpak & Dhudhany & Dhudhany & Nunak \\
\hline
\end{tabular}

Pengujian berikutnya dilakukan memasukan kalimat dalam Bahasa Jawa yang hasil proses pengecekan kalimat dapat dilihat pada Tabel 2. Pengujian dilakukan untuk mendapatkan data terkait dari aplikasi yang dirancang ini mampu melakukan proses enkripsi dan deskripsi pada kalimat yang dituliskan dengan menggunakan Bahasa Jawa.

Tabel 2 Hasil Pengujian Kalimat

\begin{tabular}{|c|l|l|l|l|}
\hline \multirow{2}{*}{ No. } & \multicolumn{4}{|c|}{ Hasil Pengujian } \\
\cline { 2 - 5 } & \multicolumn{1}{|c|}{ Plaintext } & \multicolumn{1}{|c|}{ Enkripsi } & \multicolumn{1}{c|}{ Chipertext } & \multicolumn{1}{|c|}{ Deskripsi } \\
\hline 1 & Aku mangan & Panyu daladh & Panyu daladh & Haku mangan \\
\hline 2 & Tuku sego goreng & $\begin{array}{l}\text { Gunyu beto } \\
\text { toyel }\end{array}$ & Gunyu beto toyel & Tuku sego goreng \\
\hline 3 & $\begin{array}{l}\text { Nduweni watak adil } \\
\text { lan legowo }\end{array}$ & $\begin{array}{l}\text { Dhmuthedhi } \\
\text { thagany paming } \\
\text { ngadh ngetatha }\end{array}$ & $\begin{array}{l}\text { Dhmuthedhi thagany } \\
\text { paming ngadh } \\
\text { ngetatha }\end{array}$ & $\begin{array}{l}\text { Nduweni watak } \\
\text { hadil lan legawa }\end{array}$ \\
\hline
\end{tabular}

\subsection{Uji White Box}

Pengujian White Box dilakukan untuk menguji semua perintah dan kondisi pada aplikasi yang dilakukan secara menyeluruh. Pada pengujian White Box menggunakan flowgraph untuk menggambarkan alur proses dari jalannya aplikasi Walikan.com. Pada pengujian aplikasi ini dilakukan dengan membuat flowchart sistem user terlebih dahulu untuk jalannya aplikasi dari awal dijalankan sampai akhir dari aplikasi. Flowchart sistem user dipakai menggambarkan langkah-langkah dan urutan yang dilakukan oleh user saat menjalankan aplikasi. Langkah langkah yang dapat dijalankan oleh user saat menggunakan sistem yaitu dimulai dari user menjalankan aplikasi akan tampil menu yaitu menu Walikan.com, pada menu Walikan.com user memilih akan melakukan proses enkripsi, proses deksripsi atau hapus. Jika memilih menu Tentang maka user akan masuk pada menu Tentang dan melihat isi dari menu Tentang yang berisikan informasi dari pembuat aplikasi. Selanjutnya jika memilih menu Panduan maka akan tampil menu yang ada pada Panduan dan selesai. Hasil pengujian White Box selengkapnya dapat dilihat pada tabel 3 . 
Tabel 3. Hasil pengujian White Box

\begin{tabular}{|c|l|c|c|c|}
\hline No Path & \multicolumn{1}{|c|}{ Alur Path } & Hari-1 & Hari-2 & Hari-3 \\
\hline 1 & $\begin{array}{l}\text { Mulai - Percabangan - Menu Walikan - Input - } \\
\text { Percabangan - Enkripsi - Hasil Enkripsi - Hasil } \\
\text { Aksara Jawa - Selesai. }\end{array}$ & Berhasil & Berhasil & Berhasil \\
\hline 2 & $\begin{array}{l}\text { Mulai - Percabangan - Menu Walikan - Input - } \\
\text { Percabangan - Deskripsi - Hasil Deskripsi - Hasil } \\
\text { Aksara Jawa - Selesai. }\end{array}$ & Berhasil & Berhasil & Berhasil \\
\hline 3 & $\begin{array}{l}\text { Mulai - Percabangan - Menu Walikan - Input - } \\
\text { Percabangan - Hapus - Hasil - Selesai. }\end{array}$ & Berhasil & Berhasil & Berhasil \\
\hline 4 & $\begin{array}{l}\text { Mulai - Percabangan - Percabangan - Tentang - } \\
\text { Selesai. }\end{array}$ & Berhasil & Berhasil & Berhasil \\
\hline 5 & $\begin{array}{l}\text { Mulai - Percabangan - Percabangan - Percabangan } \\
- \text { Panduan - Selesai. }\end{array}$ & Berhasil & Berhasil & Berhasil \\
\hline 6 & Mulai - Percabangan - Selesai. & Berhasil & Berhasil & Berhasil \\
\hline
\end{tabular}

\subsection{Uji Black Box}

Pengujian Black Box dilakukan untuk pengecekan fungsi - fungsi yang tersedia pada halaman menu aplikasi dapat digunakan semua atau tidak serta proses - proses yang ada disetiap halaman menu sesuai atau tidak. Hasil dari pengujian Black Box dapat dilihat pada tabel 4 hingga tabel 6 dibawah ini.

Tabel 4. Hasil Pengujian Halaman Utama Walikan.com

\begin{tabular}{|l|l|l|l|}
\hline \multicolumn{1}{|c|}{ Kelas Uji } & \multicolumn{1}{|c|}{ Skenario Uji } & Hasil Yang Diharapkan & \multicolumn{1}{c|}{ Hasil Yang Didapatkan } \\
\hline Halaman & Tampilan & Menampilkan Tampilan & Windows 10: \\
Walikan.com & Halaman Menu & Halaman Menu & [`] Berhasil \\
& Walikan.com & Walikan.co & [ ] Tidak Berhasil \\
& & & $\begin{array}{l}\text { Android Versi 8.0.0 : } \\
\text { [`] Berhasil } \\
\end{array}$ \\
& & & [ ] Tidak Berhasil \\
\hline
\end{tabular}

Pada Tabel 4 menunjukkan pengujian pada kelas uji halaman menu Walikan.com dengan skenario halaman menu Walikan.com. Pada pengujian ini dilakukan dengan menggunakan perangkat laptop dengan sistem operasi Windows 10 dan smartphone dengan sistem operasi Android Versi 8.0.0, hasil dari pengujian tersebut yaitu berhasil.

Tabel 5. Hasil Pengujian Halaman Menu Tentang

\begin{tabular}{|l|l|l|l|}
\hline \multicolumn{1}{|c|}{ Kelas Uji } & Skenario Uji & Hasil Yang Diharapkan & \multicolumn{1}{|c|}{ Hasil Yang Didapatkan } \\
\hline Halaman & Tampilan & Menampilkan Tampilan & Windows 10 : \\
Tentang & Halaman Menu & Halaman Menu Tentang & {$[\sqrt{ }]$ Berhasil } \\
& Tentang & & {$[$ ] Tidak Berhasil } \\
& & & Android Versi 8.0.0 : \\
& & & {$[\sqrt{ }]$ Berhasil } \\
& & & {$[$ Tidak Berhasil } \\
\hline
\end{tabular}


Pada Tabel 5 menunjukkan pengujian kelas uji halaman menu Tentang dengan skenario halaman Tentang. Pada pengujian ini dilakukan dengan menggunakan perangkat laptop dengan sistem Operasi Windows 10 dan smartphone dengan sistem operasi Android Versi 8.0.0, hasil dari pengujian tersebut yaitu berhasil. Pada Tabel 6 menunjukkan pengujian kelas uji halaman menu panduan dengan skenario halaman panduan. Pada pengujian ini dilakukan dengan menggunakan perangkat laptop dengan sistem Operasi Windows 10 dan smartphone dengan sistem operasi Android Versi 8.0.0, hasil dari pengujian tersebut yaitu berhasil.

Tabel 6. Hasil Pengujian Halaman Menu Panduan

\begin{tabular}{|l|l|l|l|}
\hline \multicolumn{1}{|c|}{ Kelas Uji } & Skenario Uji & Hasil Yang Diharapkan & \multicolumn{1}{c|}{ Hasil Yang Didapatkan } \\
\hline Halaman & Tampilan & Menampilkan Tampilan & Windows 10: \\
Panduan & Halaman Menu & Halaman Menu Panduan & [ $]$ Berhasil \\
& Panduan & [ ] Tidak Berhasil \\
& & & $\begin{array}{l}\text { Android Versi 8.0.0 : } \\
{[\sqrt{ }] \text { Berhasil }} \\
\text { [ ] Tidak Berhasil }\end{array}$ \\
\hline
\end{tabular}

\subsection{Pembahasan}

Tahapan proses perubahan kata atau kalimat yang dilakukan pada aplikasi Walikan.com adalah dengan melakukan pemotongan kata atau kalimat yang berawal dari 3 huruf pertama dan dicocokan pada huruf Aksara Jawa. Selanjutnya dipotong 2 huruf dan dipotong 1 huruf dicocokan pada huruf Aksara Jawa, kemudian dibalik dan selanjutnya ditampilkan dengan hasil perubahan dan ditampilkan hasil perubahan kata dengan huruf Aksara Jawa

Pada pengujian yang pertama yaitu uji fungsi dari aplikasi, dilakukan dengan uji kata dan uji kalimat. Pada uji kata, saat kata dimasukkan akan menghasilkan kata sesuai dengan proses perintah yang dipilih dan dilihat pada Tabel 1 . Hasil pengujian proses deskripsi pada huruf a, $\mathrm{i}$, $\mathrm{u}$, e ,o akan diawali huruf " $h$ ", pembacaan karakter jawa untuk huruf " $h$ " dihilangkan. Contoh pengujian untuk kata "aku" proses enkripsi menjadi "panyu" dimana saat diilakukan proses deskripsi menjadi "haku".

Ada beberapa kata yang tidak sesuai antara enkripsi dan deskripsinya, salah satu kata yang gagal yaitu kata "numpak" dimana kata tersebut apabila dienkripsi akan berubah menjadi "dhudhany" dan apabila kata "dhudhany" tersebut dilakukan proses deskripsi maka akan berubah menjadi "nunak" ini terjadi karena pada kata "numpak" apabila dienkripsi terbaca oleh sistem huruf "dhu, d, ha, ny" sedangkan pada pola sistem deskripsi kata "dhudhany" terbaca huruf "dhu, dha, ny" yang apabila di proses menjadi kata "nunak", maka dapat disimpulkan bahwa input dengan memasukkan kata dapat diproses oleh aplikasi dan berjalan dengan baik namun ada beberapa kata yang tidak sesuai antara kata hasil dari proses enkripsi apabila hasil tersebut dilakukan proses deskripsi.

Pengujian selanjutnya dengan memasukkan kalimat yang terdiri dari lebih dari satu kata dalam Bahasa Jawa. Pada pengujian kalimat saat dimasukkan lebih dari satu kata maka akan menghasilkan yang sesuai dengan proses yang dipilih, ini tampak terlihat pada Tabel 2 sehingga dapat diambil kesimpulan bahwa input lebih dari satu kata dapat menghasilkan output juga lebih dari satu kata yang sesuai dengan proses yang dipilih dan dapat berjalan dengan baik tanpa kendala.

Pada pengujian kedua yaitu pengujian White Box dimana pengujian ini dilakukan dengan menggambarkan flowgraph terlebih dahulu dimana flowgraph dibentuk dari perubahan pada 
penggambaran flowchart. Pengujian yang dilakukan dengan menguji path yang didapat dari hasil perhitungan cyclomatic complexity, pada perhitungan tersebut terdapat enam path dan setiap path yang didapatkan diuji selama tiga hari dengan berhasil tidak memiliki kendala, hasil dari pengujian white box ini dapat dilihat sesuai dengan urutan path yaitu path 1 , path 2 , path 3 , path 4 , path 5 dan path 6 pada Tabel 3. Dari semua hasil yang didapat dapat disimpulkan jika aplikasi Bahasa Walikan dapat berjalan dengan baik dan tanpa kendala.

Pada pengujian ketiga yaitu pengujian Black Box dimana pengujian ini dilakukan dengan menjalankan aplikasi pada dua perangkat yaitu laptop dengan sistem operasi Windows 10 dan smartphone Android versi 8.0.0 yang bisa dilihat hasilnya sesuai dengan halaman menu yang pilih yaitu halaman menu walikan pada Tabel 4 , halaman menu tentang pada Tabel 5, halaman menu panduan pada Tabel 6 dari hasil yang terdapat pada tabel tersebut dapat disimpulkan bahwa aplikasi kriptografi Bahasa Walikan dapat dijalankan pada perangkat laptop dan perangkat smartphone.

\section{Kesimpulan}

Berdasarkan hasil dari pengujian yang telah dilakukan terhadap aplikasi Walikan.com dengan Metode Basa Walikan dapat disimpulkan:

1. Dari uji fungsi didapatkan hasil yaitu aplikasi dapat berjalan dan melakukan proses enkripsi dan proses deskripsi sesuai dengan rancangan aplikasi yang dibuat, khusus untuk dua buah konsonan $\mathrm{m}$ dan $\mathrm{p}$ yang berdekatan proses enkripsi dan proses deskripsi dilakukan secara terpisah atau perkarakter.

2. Berdasarkan pengujian dengan White-Box dan Black-Box dari semua hasil yang didapatkan dapat disimpulkan jika aplikasi Walikan dapat dijalankan sesuai dengan rancangan yang telah dibuat.

\section{Daftar Pustaka}

[1] Wijaya, R. E., \& Mangoting, Y. (2014). Boso Walikan Malangan Dalam Perspektif Earning Management: Suatu Kreativitas Bahasa Akuntansi. Seri Akuntansi Multiparadigma Indonesia, 1(1), 47-56.

[2] Prayogi, I. (2013). Proses Pembentukan Slang Malang. SASINDO, 1(1 Januari).

[3] Hermawan, N. F. (2014). Basa Walikan "Slang Jawa". El-Wasathiya: Jurnal Studi Agama, 2(2), 224-245.

[4] Qurniawan, W., Wintolo, H., \& Nugraheny, D. (2012). Penerapan Sistem Keamanan Dengan Kriptografi Advanced Encryption Standard (AES) Dan Key Administrator Pada Sinkronisasi File. Compiler, 1(2).

[5] Riyadi, W. (2017). Kriptografi Symmetric-Key Cryptosystem Dengan Metode AES (Advanced Encryption Standard) 256bit. Jurnal Processor, 11(1), 709-719.

[6] Purnama, B. (2017). Pengamanan Pesan Rahasia Melalui Kriptografi Vigenere Cipher Dengan Kunci Berlapis. Jurnal Processor, 9(3), 264-269.

[7] Widodo, A. P., Sarwoko, E. A., Suharto, E., \& Siahaan, J. F. O. (2016). Pengamanan Data Foto Pada Perangkat Os Android Menggunakan Teknik Kriptografi Hill Cipher. JISKA (Jurnal Informatika Sunan Kalijaga), 1(2). 
[8] Muttaqin, M., Sajati, H., \& Retnowati, N. (2014). Penerapan Sistem Keamanan Menggunakan Cryptography Pada Aplikasi Chatting Dengan Memodifikasi Algoritma Rivest Shamir Adleman (RSA). Compiler, 3(1).

[9] Wintolo, H., Retnowati, N. D., \& Fendriyanto, P. (2013, December). Penerapan Alogritma Lipat Pada Steganografi Yang Memanfaatkan Rms (Record Management System) Di J2ME. In Conference SENATIK STT Adisutjipto Yogyakarta (Vol. 1, pp. 76-84).

[10] Wintolo, H., Pujiastuti, A., \& Imam, M. (2018, November). Use of Lipat Algorithm on Android to Secure Data Communication in Social Media. In Conference SENATIK STT Adisutjipto Yogyakarta (Vol. 4, pp. 375-384). 
Hero Wintolo, Asih Pujiastuti, Ellyana Mega Dewantri Astuti

KJK-214 